\title{
Endoscopic and histopathological features of the upper gastrointestinal system polyps: evaluation of 12.563 procedures
}

\author{
Hüseyin Çiyiltepe ${ }^{1}$, Durmuş Ali Çetin ${ }^{1}$, Ebubekir Gündeş ${ }^{1}$, Ulaş Aday ${ }^{1}$, Aziz Serkan Senger ${ }^{1}$, Selçuk Gülmez ${ }^{1}$, Sabiye Akbulut ${ }^{2}$, Mustafa Duman ${ }^{1}$ \\ ${ }^{1}$ Clinic of Gastroenterological Surgery, Kartal Kosuyolu High Specialization Health Application and Research Center, Istanbul, Turkey \\ ${ }^{2}$ Clinic of Gastroenterology, Kartal Kosuyolu High Specialization Health Application and Research Center, Istanbul, Turkey
}

\begin{abstract}
Objective: With the widespread use of esophagogastroduodenoscopy (EGD) in recent years, upper gastrointestinal system polyps have started to be encountered more often. Although most patients with gastric polyps are asymptomatic, these are important due to their malign potential, and gastric cancer may develop if left untreated.

Material and Methods: Records of 12.563 patients who underwent EGD at Kartal Kosuyolu High Specialization Health Application and Research Center for any reason between January 2013 and June 2016 were reviewed retrospectively. Patients with at least 1 histopathologically proven polyp were included in this study.

Results: A total of 12.563 endoscopic procedures of the upper gastrointestinal system were investigated and 353 (2.8\%) polypoid lesions were detected. Mean age of these patients was 56.3 years and 241 (68.3\%) of the patients were female. Gastric polyps were found most commonly in the antrum (50.1\%) and of all gastric polyps, 245 (69.5\%) were less than $1 \mathrm{~cm}$. Histopathological evaluation showed that hyperplastic polyp (HP) ( $n=151,42.8 \%)$ was the most common polyp type, followed by fundic gastric polyp (FGP) ( $n=51,14.4 \%)$. Non-polyp gastric mucosa evaluation of 298 patients revealed that $34.9 \%$ of the cases were Helicobacter pylori positive, $19.4 \%$ had intestinal metaplasia, and $11.4 \%$ had atrophic gastritis.
\end{abstract}

Conclusion: Polyps of the upper gastrointestinal system are generally detected coincidentally as they have no specific symptoms. Polypectomy is required for gastric polyps because of their potential for malign transformation according to medical evidence.

Keywords: Upper gastrointestinal system, polyp, endoscopy, hiperplastic polyp, fundic gastric polyp

Cite this article as: Çiyiltepe $H$, Çetin DA, Gündeş E, Aday $U$, Senger AS, Gülmez S, et al. Endoscopic and histopathological features of the upper gastrointestinal system polyps: evaluation of 12.563 procedures. Turk J Surg 2019; 35 (2): 98-104

Corresponding Author Hüseyin Çiyiltepe

E-mail: drciyiltepe@hotmail.com

Received: 12.03 .2018

Accepted: 04.05.2018

Available Online Date: 13.06 .2019

OC Copyright 2019 by Turkish Surgical Society Available online at www.turkjsurg.com

DOI: $10.5578 /$ turkjsurg.4155

\section{INTRODUCTION}

In recent years, gastric polyps have started to be encountered more often with the widespread use of esophagogastroduodenoscopy (EGD) (1). Any abnormal growths projecting above the plane of the mucosa into the lumen of the stomach are defined as "gastric polyps". Gastric polyps most frequently originate in the mucosa, which may even be submucosal or extrinsic $(2,3)$.

Incidence rate of gastric polyps ranges from $2 \%$ to $6 \%$ during upper endoscopy and less than $1 \%$ in the general population; however, it has begun to gradually increase due to the high amount endoscopic procedures $(4,5)$.

The British Society of Gastroenterology has classified gastric polyps into 2 different groups (6) (Table 1). The first group is epithelial polyps, such as fundic gland polyps (FGP), hyperplastic polyps (HP), adenomatous polyps (AP), hamartomatous polyps and non-hamartomatous-polyposis syndromes. The second group is non-mucosal intramural polyps, such as the gastrointestinal stromal tumor, leiomyoma, inflammatory fibroid polyp, fibroma and fibromyoma, lipoma, ectopic pancreas, neurogenic and vascular tumors, and neuroendocrine tumors (carcinoids).

It has been reported that hyperplastic polyps are the most common type especially at the areas where Helicobacter pylori infection is common. With the chronic use of proton pomp inhibitors (PPI) and eradication of H. pylori, FGP has become more common $(7,8)$.

Most patients with gastric polyps are asymptomatic, which can be found during routine EGD. Larger polyps can cause bleeding, abdominal pain and even gastric outlet obstruction. They are important because they have malign potential and gastric cancer may develop if they are untreated (9). 
Table 1. Classification of gastric polyps (The British Society of Gastroenterology, 2009)

\begin{tabular}{|c|c|}
\hline Epithelial Polyps & $\begin{array}{c}\text { Non-mucosal Intramural } \\
\text { Polyps }\end{array}$ \\
\hline Fundic gland polyp & $\begin{array}{c}\text { Gastrointestinal stromal } \\
\text { tumor }\end{array}$ \\
\hline Hyperplastic polyp & Leiomyoma \\
\hline Adenomatous polyp & Inflamatoryfibroid polyp \\
\hline Hamartomatous polyp & Fibromaand fibromyoma \\
\hline $\begin{array}{l}\text { - } \quad \text { Juvenile polyp } \\
\text { - } \quad \text { Peutz-Jeghers'syndrome } \\
\text { - } \quad \text { Cowden's syndrome } \\
\text { Polyposis syndromes } \\
\text { (non-hamartomatous) } \\
\text { - } \quad \text { Juvenile polyposis } \\
\text { - } \quad \text { Familial adenomatous polyposis }\end{array}$ & $\begin{array}{c}\text { Lipoma } \\
\text { Ectopic pancreas } \\
\text { Neurogenic and vascular } \\
\text { tumours } \\
\text { Neuroendocrine tumours } \\
\text { (carcinoids) }\end{array}$ \\
\hline
\end{tabular}

This study aimed to present demographic, clinical, endoscopic and pathological characteristics of patients with gastric polyps and the frequency of these lesions.

\section{MATERIAL and METHODS}

\section{Study Design}

After receiving approval from the review board (Kartal Dr. Lutfi Kirdar Educational and Research Hospital Ethics Comittee, Date of Approval: 27/10/2016; Reference number: 2016.4/3-14), we retrospectively reviewed the patients who had undergone elective EGDs at Kartal Kosuyolu High Specialization Health Application and Research Center for any reason between January 2013 and June 2016. All endoscopic procedures were performed by gastroenterologists or gastroenterology surgeons. All patients had signed informed consents before EGDs. Patients with previous history of gastric resection and on whom we had performed therapeutic procedures such as sclerotherapy, endoscopic variceal ligation, percutaneous endoscopic gastrostomy or stent placement were excluded.

Patients with gastric polypoid lesions other than those with endoscopically suspected GIST or ectopic pancreas underwent polyp sampling and/or polypectomy. Endoscopic ultrasonography was performed to diagnose GIST.

Information about patients' age, gender and polyp location, size, number, histological classification and gastric mucosal changes were obtained from endoscopic and pathological reports. Histological classification of the polyps was carried out according to the guidelines of the British Society of Gastroenterology. The samples taken from normal stomach tissue surrounding polyps were evaluated in terms of $\mathrm{H}$. pylori, chronic atrophic gastritis and intestinal metaplasia. No biopsy was done for the diagnosis of endoscopic GIST or ectopic pancreas.

\section{Statistical Analysis}

All statistical analyses were performed using SPSS (version 15, Chicago, IL ,USA). Quantitative variables were described using mean \pm SD and categorical variables were described using frequency and proportion. Comparison of the categorical data between the two groups was analyzed by Chi-square test and $p$ values $<0.05$ were considered statistically significant. One-way ANOVA test was used to compare the relationship between $H$. pylori, IM and AG and three subgroup of polyps.

\section{RESULTS}

We investigated a total of 12.563 endoscopic procedures of the upper gastrointestinal system performed at our clinic within the last 3.5 years and detected 353 (2.8\%) polypoid lesions. Mean age of these patients was $56.3 \pm 12.8$ (18-85) years and 241 (68.3\%) of the patients were female, while 112 (31.7\%) were male (Table 2).

While a single polyp was seen in 298 (84.5\%) patients, multiple polyps were detected in 55 (15.5\%). Endoscopic evaluation showed that 177 (50.1\%) of the polyps were located in the antrum, 71 (20.1\%) in the corpus, 43 (12.2\%) in the fundus, 27 (7.6\%) in the cardia, $14(4 \%)$ in multiple areas of the stomach, and 21 (5.9\%) were located either in the distal esophagus or the duodenum.

When polyp sizes, which were endoscopically measured, were classified into 3 different groups, it was seen that the number of polyps smaller than $5 \mathrm{~mm}$ was 120 (33.9\%), the number of the ones sized between 5 to $10 \mathrm{~mm}$ was 125 (35.4\%), and the number of the ones larger than $10 \mathrm{~mm}$ was 108 (30.5\%).

Pathological evaluation of the endoscopic polypectomies can be seen in Table 2. Pathological investigation demonstrated that HP ( $n=151,42.8 \%)$ was the most frequently detected one followed by FGP ( $n=51,14.4 \%)$, gastrointestinal stromal tumor $(n=48,13.6 \%)$, and polypoidfoveolar hyperplasia ( $n=44,12.5 \%)$. While 7 (2\%) patients were diagnosed with adenomatous polyps, two were diagnosed with low grade dysplasia. According to the pathology results of the group referred to as "other," which had a total of 21 (5.9\%) patients, 9 patients had squamous papilloma, 3 had neuroendocrine tumor, 1 had lymphangiectasis, 1 had blood-fibrin mass, and 7 had foreign-body reaction granulation tissue.

Non-polyp gastric mucosa evaluation of 298 patients revealed that $34.9 \%$ of the cases were H. pylori positive, $19.4 \%$ had intestinal metaplasia, and $11.4 \%$ had atrophic gastritis. When H. pylori positivity was investigated separately in HP, FGP, and polypoidfoveolar hyperplasia cases, it was seen that positivity was significantly higher in cases with HP (Table 3). Moreover, H. pylori positivity was separately evaluated according to HP sizes. There was a statistically significant relationship between polyp sizes and $H$. pylori positivity (Table 4). 


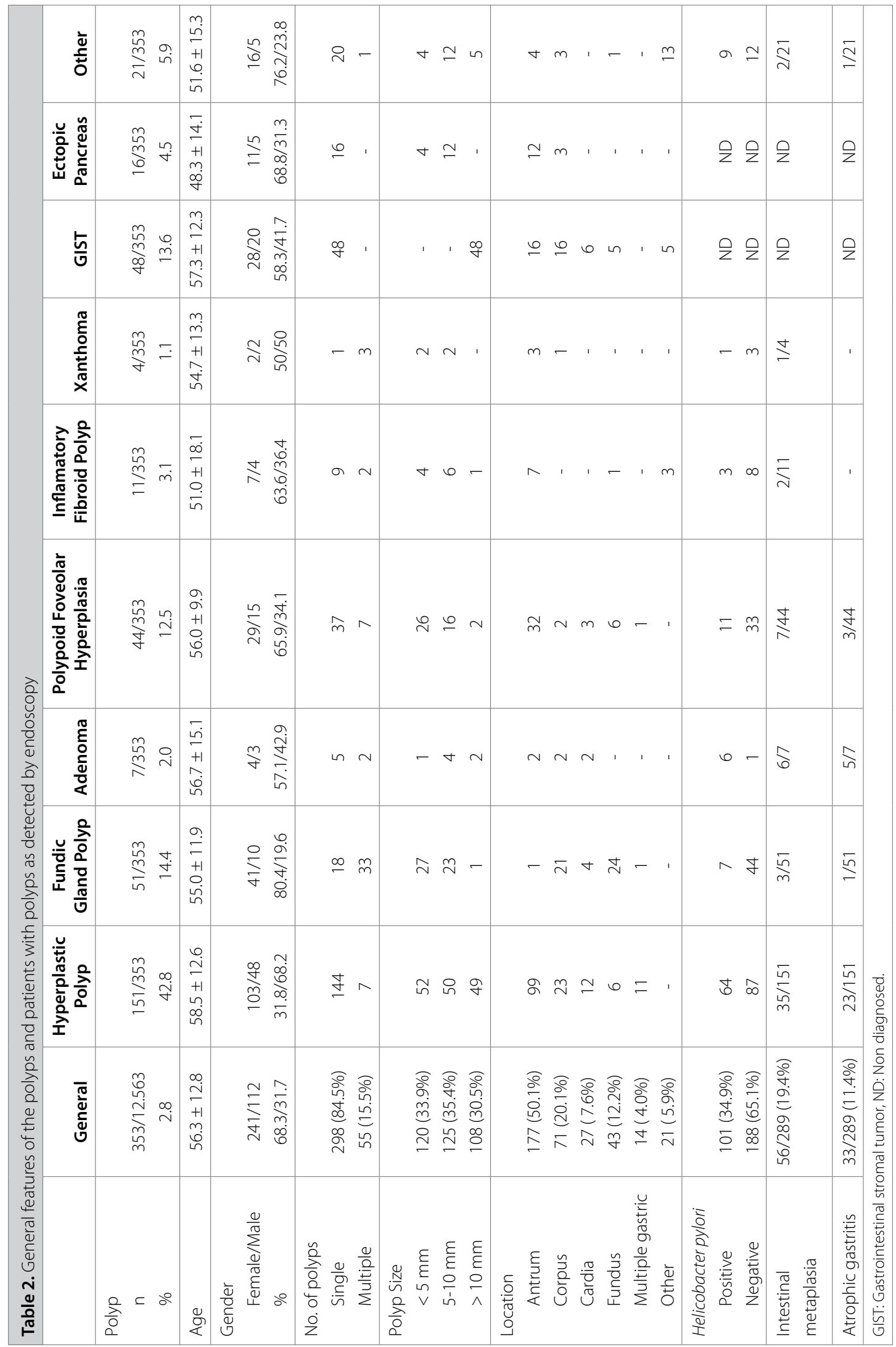


Table 3. Relationship between Helicobacter pylori, IM and AG and three types of polyps

\begin{tabular}{|l|c|c|c|c|}
\hline & Hyperplastic polyp & Fundic gland polyp & Polypoid foveolar hyperplasia & p \\
\hline Helicobacter pylori & & & 11 & $<0.05^{*}$ \\
$\quad$ - Positive & 64 & 7 & 33 & \\
\hline - Negative & 87 & 44 & $7 / 44$ & - \\
\hline Intestinal metaplasia (IM) & $35 / 151$ & $3 / 51$ & $3 / 44$ & - \\
\hline Atrophic gastritis (AG) & $23 / 151$ & $1 / 51$ & & \\
\hline * Statistically significant. & & & & \\
\hline
\end{tabular}

Table 4. Relationship between Helicobacter pylori and size of hyperplastic polyps

\begin{tabular}{|l|c|c|c|}
\hline Polyp size & Hyperplastic polyp H. pylori + & Hyperplastic polyp H. pylori - & p \\
\hline$<5 \mathrm{~mm}$ & 16 & 36 & \\
\hline $5-10 \mathrm{~mm}$ & 17 & 18 & \multirow{2}{*}{$0.001^{*}$} \\
\hline$>10 \mathrm{~mm}$ & 31 & 87 & \\
\hline Total & 64 & & \\
\hline * Statistically significant. & & & \\
\hline
\end{tabular}

\section{DISCUSSION}

As polyps of the upper gastrointestinal system are generally small and asymptomatic, they are coincidentally detected by EGDs performed for other purposes. Although the incidence of polyps and their histopathological features vary according to different geographical areas, it is seen in about $0.8-2.4 \%$ of the general population. While the rate of polyps randomly detected in upper endoscopy procedures performed for other purposes was stated to be $2.2 \%$ in a large series conducted in our country, the same rate was reported to be $2.6 \%$ in Far Eastern countries, and $6 \%$ in the US $(8,10,11)$. The main reason of the differences seen among geographical areas pertains to $H$. pylori prevalence and PPI use. The rate of polyps detected by endoscopies in our study was $2.8 \%$ and this result was in line with the literature data.

Mean age of the patients detected to have polyps was 56.3 , and mean age figures among the groups were similar. Other studies in the literature have also reported that patients of a similar age group frequently had gastric polyps.

A great majority of the patients diagnosed to have polyps within the scope of the study was female (68\%). Many studies conducted in our country reported that polyps were seen more frequently in the female population and this rate varied between 58 and $67 \%(12,13)$. It was suggested that this rate was higher in our study as the number of female patients was higher as well. No statistically significant relationship, however, was found between the histopathological features of polyps and gender $(p<0.05)$.

Data offered by studies in the literature suggest that gastric polyps are generally singular, located in the antrum, and are smaller than $1 \mathrm{~cm}$ (14). The results of our study also revealed that they were singular in $84 \%$ of the patients, located in the antrum in about half of them, and a great majority (70\%) was smaller than $1 \mathrm{~cm}$.

Although there is no consensus on the ways in which asymptomatic polyps should be approached in the general literature, the general approach of endoscopists is to take biopsy samples from the polyp and perform polypectomy depending on the pathology results. The preferred mode of treatment in our own clinic is to excise or sample all polyps especially larger than $5 \mathrm{~mm}$ accompanied by snare or with hot biopsy forceps. Muehldorfer et al. have found out remarkable differences only between the pathology results of polyp biopsies and polypectomy specimens when they were compared and suggested polypectomy be performed on polyps larger than $5 \mathrm{~mm}$ (15).

HPs are the kind of polyps seen most frequently among all benign gastric polyps and are generally smaller than $2 \mathrm{~cm}$, singular, sessile or pedicled, frequently located in the antrum but can be seen in all gastric localizations (6). Chronic atrophic gastritis and $H$. pylori positivity and association are often seen in gastric mucosa samples accompanying HP (16). The results of our study did not only reveal a statistically significant relationship between HP and $H$. pylori positivity but also a significant relationship between polyp size and H. pylori positivity (Tables 3,4).

Though rare, there can be malign transformations in HPs, which proves to be significant as there can be a possible increase in the risk of associated synchronous cancer development. Some sources cite the rate of malign transformation to be between 1.9 and 19\% (17). It has been reported by some investigators that increased size of the polyp $(>1 \mathrm{~cm}$ ) increases the risk of 
malignant transformation and p53 genetic mutation is effective in this transformation (18). Similarly, some researchers have reported that the risk of cancer development in the surrounding gastric mucosa is higher than the polyp itself in HP cases and multiple biopsies should definitely be taken from the surrounding mucosa (6). In our study group, adenomatous changes were seen in 6 patients (3.9\%) but no malign transformations were detected in the pathological evaluation of the surrounding gastric mucosa.

FGPs, on the other hand, are polyps which account for 16$51 \%$ of epithelial polyps and can be associated with sporadic or familial adenomatous polyposis (FAP) syndrome, are mostly smaller than $1 \mathrm{~cm}$ and located in the gastric corpus and fundus (19). In a study by Weston et al., the authors have stated that correct diagnosis can be established with a high probability through observation by a single endoscopist (20). Its pathogenesis is not known clearly. Dysplasia development is lower than $1 \%$ in sporadic fundic gland polyps and there is no relationship between atrophic gastritis and H. pylori (21).

There is adenomatous polyposis coli (APC) genetic mutation in FAP-related FGP cases and multiple polyps covering the whole gastric corpus are seen in these cases. The risk of malign transformation is quite high in FAP-related FGPs (25-41\%) in comparison to the sporadic form (22). Furthermore, it has been suggested that colon involvement should also be investigated in these cases. There is, however, no adequate data in the literature as to the number of gastric polyps to be suspicious of FAP. There are studies which recommend sigmoidoscopy especially for patients under the age of 40 with multiple FGPs and for cases whose pathology results indicate dysplasia existence $(6,23)$.

When the studies published in Turkey were taken into consideration, it was seen that the number of HPs in our study was lower than other studies, whereas the number of FGPs was higher (Table 5). We think that the reason for this discordance is related to the fact that the patients in our hospital were on antiaggregant therapy for their cardiac comorbidities alongside with regular use of PPI and the gradual yearly increase in PPI administration in the general population. Although previous studies have reported that $H$. pylori positivity in patients with gastric polyps was about $50-70 \%$ in Turkey, we found $\mathrm{H}$. pylori positivity to be $34.9 \%$ in our study probably because of the same reason $(12,24)$.

While there is a relationship between FGP formation and chronic PPI administration according to some authors, there is no such relationship according to many others. The inverse relationship between FGP and $H$. pylori, however, is clearly known (25-27). The subgroup evaluation conducted within the scope of our study revealed that there was a statistically significant high rate of $\mathrm{H}$. pylori positivity in HPs, whereas there was no relationship between the two in FGPs (Table 3).

APs are true neoplasms which are the precursors of gastric cancers. They account for 3-26\% of benign epithelial gastric polyps and are mostly singular, smaller than $2 \mathrm{~cm}$, can be seen in all areas of the stomach but are more often localized in the antrum (28). When the surrounding gastric mucosa is scrutinized it is seen that most of it is associated with atrophic gastritis and intestinal metaplasia. It has no proven relationship to $H$. pylori. Although various studies have reported that the neoplastic transformation is between 6 and $47 \%$, this rate is higher in polyps larger than $2 \mathrm{~cm}(29,30)$. In our study group, 2 out of 7 patients (28.5\%) had low grade dysplasia. It has been suggested that all parts of the stomach should be carefully investigated for mucosal anomalies in cases with adenomatous polyps and a control EGD should be conducted after 6 months if incomplete polypectomy was performed (6).

Table 5. Comparison with other studies in the literature

\begin{tabular}{|c|c|c|c|c|c|c|c|c|c|}
\hline Author & Country & Year & $\begin{array}{l}\text { Number of } \\
\text { polyps (\%) }\end{array}$ & $\begin{array}{l}\text { Hyperplastic } \\
\text { polyp }\end{array}$ & $\begin{array}{l}\text { Fundic } \\
\text { gastric } \\
\text { polyp }\end{array}$ & Adenomas & $\begin{array}{c}\text { Helicobacter } \\
\text { pylori }\end{array}$ & $\begin{array}{l}\text { Atrophic } \\
\text { gastritis }\end{array}$ & $\begin{array}{c}\text { Intestinal } \\
\text { metaplasia }\end{array}$ \\
\hline Carmack et al. (8) & USA & 2009 & $7.877 / 12.564$ (6.5\%) & $17 \%$ & $77 \%$ & $0.7 \%$ & $2.2 \%$ & $22 \%$ & $4.9 \%$ \\
\hline Sonnenberg et al. (7) & USA & 2015 & $71.575 / 812.926(8.8 \%)$ & $18.5 \%$ & $79.9 \%$ & $0.9 \%$ & $1.34 \%$ & $0.7 \%$ & $2.1 \%$ \\
\hline Cao et al. (1) & China & 2012 & $254 / 24.121(1 \%)$ & $28.3 \%$ & $50.6 \%$ & $0.05 \%$ & $42.2 \%$ & - & - \\
\hline Fan NN et al. (11) & China & 2015 & 4.043/157.902 (2.5\%) & $25 \%$ & $65 \%$ & $1.8 \%$ & $4.6 \%$ & - & - \\
\hline $\begin{array}{l}\text { Gencosmaoglu et al. } \\
\text { (12) }\end{array}$ & Turkey & 2003 & $91 / 2.630(3.4 \%)$ & $46 \%$ & $14 \%$ & $2.7 \%$ & $49 \%$ & - & $36 \%$ \\
\hline Sezikli et al. (14) & Turkey & 2014 & $123 / 6.607(1.8 \%)$ & $65.9 \%$ & $0.8 \%$ & $10.6 \%$ & $32.5 \%$ & - & - \\
\hline Büyükaşık et al. (24) & Turkey & 2015 & $59 / 55.987(0.1 \%)$ & $69 \%$ & $3.3 \%$ & $6.7 \%$ & $68.2 \%$ & $56 \%$ & $39 \%$ \\
\hline Atalay et al. (13) & Turkey & 2015 & $174 / 14.240(1.2 \%)$ & $83.9 \%$ & $6.1 \%$ & $7.4 \%$ & - & - & - \\
\hline Vatansever et al. (10) & Turkey & 2015 & $666 / 29.940(2.2 \%)$ & $36.2 \%$ & $8.3 \%$ & $1.9 \%$ & - & - & - \\
\hline Present study & Turkey & 2016 & $353 / 12.563(2.8 \%)$ & $42.8 \%$ & $14.4 \%$ & $2.0 \%$ & $34.9 \%$ & $11.4 \%$ & $19.4 \%$ \\
\hline
\end{tabular}


When the malign transformation potential of polyps and their similarities during endoscopic procedures are taken into consideration, the British Society of Gastroenterology suggests that all polyps larger than $5 \mathrm{~mm}$ should be completely excised or sampled if possible. The British Society of Gastroenterology also suggests that at least 2 biopsies should be conducted for polyps smaller than $1 \mathrm{~cm}$, while 4 or more biopsies should be done for polyps larger than $1 \mathrm{~cm}$ in cases where total polypectomy is not viable. It has been proposed that endoscopic control should be carried out following 1 year after total polypectomy in HPs, and it has been reported that no follow-ups are necessary in patients diagnosed with HP but were seen to have no polyps at the end of the first year and in FGP cases (6).

\section{Study Limitations}

The limitations of this study include its retrospective design, single center and the absence of stomach mucosa specimens around the polyp in some patients.

\section{CONCLUSION}

Polyps of the upper gastrointestinal system are generally detected coincidentally as they have no specific symptoms and prove to be significant because of their potential for malign transformation. Although their endoscopic images vary, they do not provide physicians with clear information on their pathology. Polypectomy should be performed for the ones which can be excised when they are detected, and follow-up should be carried out following the performance of biopsies with an adequate number and depth for polyps which cannot be removed.

Ethics Committee Approval: Ethics committee approval was received for this study from the Ethics Committee of Kartal Dr. Lutfi Kirdar Training and Research Hospital (2016.4/3-14).

Informed Consent: Informed consent was not received due to the retrospective nature of the study.

Peer-review: Externally peer-reviewed.

Author Contributions: Consept - H.Ç.; Design - H.Ç., U.A.; Supervision M.D., S.A.; Data Collection and/or Processing - S.G., A.S.S.; Analysis and Interpretation - E.G.; Literature Search - D.A.Ç., H.Ç.; Writing Manuscript - H.Ç., E.G.; Critical Reviews - U.A., M.D.

Conflict of Interest: The authors have no conflicts of interest to declare.

Financial Disclosure: The authors declared that this study has received no financial support.

\section{REFERENCES}

1. Cao H, Wang B, Zhang Z, Zhang H, Qu R. Distribution trends of gastric polyps: an endoscopy data base analysis of 24121 northern Chinesepatients. J Gastroenterol Hepatol 2012; 27: 1175-80. [CrossRef]

2. Park DY, Lauwers GY. Gastric polyps: classification and management. Arch Pathol Lab Med 2008; 132: 633-40.

3. Oberhuber G, Stolte M. Gastric polyps: an update of their pathology and biological significance. Virchows Arch 2000; 437: 581-90. [CrossRef]
4. Carmack SW, Genta RM, Graham DY, Lauwers GY. Management of gastric polyps: a pathology-based guide for gastroenterologists. Nat Rev Gastroenterol Hepatol 2009; 6: 331-41. [CrossRef]

5. García-alonso FJ, MartínMateos RM, González-Martín JA, Foruny JR, VázquezSequeiros E, Boixeda de Miquel D. Gastric polyps: analysis of endoscopic and histological features in our center. Rev Esp Enferm Dig 2011; 103: 41620. [CrossRef]

6. Goddard AF, Badreldin R, Pritchard DM, Walker MM, Warren B. The management of gastric polyps. Gut 2010; 59: 1270-6. [CrossRef]

7. Sonnenberg A, Robert MG. Prevalence of benign gastric polyps in a large pathology database. Dig Liver Dis 2015; 47: 164-9. [CrossRef]

8. Carmack SW, Genta RM, Schuler CM, Saboorian MH. The Current spectrum of gastric polyps: a 1year National study of over 120,000 patients. Am J Gastroenterol 2009; 104: 152432. [CrossRef]

9. Kumar A, Quick CR, Carr-Locke DL. Prolapsing gastric polyp, an unusual cause of gastric outlet obstruction: a review of the pathology and management of gastric polyps. Endoscopy 1996; 28: 452-5. [CrossRef]

10. Vatansever S, Akpinar Z, Alper E, Ipek S, Yazıcıoğlu N, Ekinci N, et al. Gastric polyps and polypoid lesions: Retrospective analysis of 36650 endoscopic procedures in 29940 patients. Turk J Gastroenterol 2015; 26: 117-22. [CrossRef]

11. Fan NN, Yang J, Sun G, Lu ZS, Ling Hu EQ, Wang XD, et al. Changes in the spectrum of gastric polyps in the Chinese population. World J Gastroenterol 2015; 21:9758-64. [CrossRef]

12. Gencosmanoglu R, Sen-Oran E, Kurtkaya-Yapicier O, Avsar E, Sav A, Tozun N. Gastric polypoid lesions: analysis of 150 endoscopic polypectomy specimens from 91 patients. World J Gastroenterol 2003; 9: 2236-9. [CrossRef]

13. Atalay R, Solakoğlu T, Özer Sarı S, Köseoğlu H, Akın FE, Bolat AD, et al. Evaluation of gastric polyps detected by endoscopy: A single-center study of a four-year experience in Turkey. Turk J Gastroenterol 2014; 25: 370-3. [CrossRef]

14. Sezikli M, Çetinkaya ZA, Şirin G, Atar E, Eroğlu D, et al. Prevalence of gastric polyps during upper gastrointestinal system endoscopy and their location, size, and histopathologic features. Endoscopy 2014; 22: 38-40.

15. Muehldorfer SM, Stolte M, Martus P, Hahn EG, Ell C. Diagnostic accuracy of forceps biopsy versus polypectomy for gastric polyps: a prospective multicentre study. Gut 2002; 50: 465-70. [CrossRef]

16. Ohkusa T, Miwa H, Hojo M, Kumagai J, Tanizawa T, Asaoka D, et al. Endoscopic, histological and serologic findings of gastric hyperplastic polyps after eradication of Helicobacter pylori: comparison between responder and non-responder cases. Digestion 2003; 68: 57-62. [CrossRef]

17. Dirschmid K, Platz-Baudin C, Stolte M. Why is the hyperplastic polyp a marker for precancerous condition of the gastric mucosa. Virchows Arch 2006; 448: 80-4. [CrossRef]

18. Yao T, Kajiwara M, Kuroiwa S, Iwashita A, Oya M, Kabashima A, Tsuneyoshi M. Malignant transformation of gastric hyperplastic polyps: alteration of phenotypes, proliferative activity, and p53 expression. Hum Pathol 2002; 33: 1016-22. [CrossRef]

19. Morais DJ, Yamanaka A, Zeitun JM, Andreollo NA. Gastric polyps: a retrospective analysis of 26,000 digestive endoscopies. Arq Gastroenterol 2007; 44: 14-7. [CrossRef]

20. Weston BR, Helper DJ, Rex DK. Positive predictive value of endoscopic features deemed typical of gastric fundic gland polyps. J Clin Gastroenterol 2003; 36: 399-402. [CrossRef] 
21. Stolte M, Vieth M, Ebert MP. High-grade dysplasia in sporadic fundic gland polyps: clinically relevantor not. Eur J Gastroenterol Hepatol 2003; 15: 1153-6. [CrossRef]

22. Burt R. Clinical management; gastric fundic gland polyps. Gastroenterology 2003; 125: 1462-9. [CrossRef]

23. Jung A, Vieth M, Maier O, Stolte M. Fundic gland polyps (Elster'scysts) of the gastric mucosa. A marker for colorectal epithelial neoplasia? Pathol Res Pract 2002; 198: 731-4. [CrossRef]

24. Buyukasik K, Sevinç MM, Gündüz UR. Upper gastrointestinal tract polyps: what do we know about them? Asian Pac J Cancer Prev 2015; 16: 2999-3001. [CrossRef]

25. Jalving M, Koornstra JJ, WesselingJ, Boezen HM, Jong SD, Kleıbeuker $J H$. Increased risk of fundic gland polyps during long-term proton pump inhibitor therapy. Aliment Pharmacol Ther 2006; 24: 1341-8. [CrossRef]

26. Cao H, Qu R, Zhang Z, Xinyue K, Shan W, Kui J, et al. Sporadic fundic gland polyps are not associated with proton pump inhibitors therapy but negatively correlate with helicobacter pylori infection in China. Chin Med J 2013; 127: 1239-43.
27. Camilo SM, Almeida ÉC, Miranzi BA, Silva JC, Nomelini RS, Etchebehere RM. Endoscopic and histopathologic gastric changes in chronic users of proton-pump inhibitors. Arq Gastroenterol 2015; 52: 59-64. [CrossRef]

28. Yoshihara M, Sumii K, Haruma K, Kiyohira K, Hattori N, Kitadai Y, et al. Correlation of ratio of serum pepsinogen I and II with prevalence of gastric cancer and adenoma in Japanese subjects. Am J Gastroenterol 1998; 93: 1090-6. [CrossRef]

29. Saito K, Arai K, Mori M, Kobayashi R, Ohkil. Effect of Helicobacter pylori eradication on malignant transformation of gastric adenoma. Gastrointest Endosc 2000; 52: 27-32. [CrossRef]

30. Yoon WJ, Lee DH, JungYJ, Jeong JB, Kim JW, Kim BG, et al. Histologic characteristics of gastric polyps in Korea: emphasis on discrepancy between endoscopic forceps biopsy and endoscopic mucosal resection specimen. World J Gastroenterol 2006; 12: 4029-32. [CrossRef]

\section{ORIJINAL ÇALIŞMA-ÖZET}

Turk J Surg 2019; 35 (2): 98-104

\section{Üst gastrointestinal sistem endoskopisinde saptanan poliplerin endoskopik ve histopatolojik özellikleri: 12.563 işlemin değerlendirilmesi}

Hüseyin Çiyiltepe ${ }^{1}$, Durmuş Ali Çetin ${ }^{1}$, Ebubekir Gündeş ${ }^{1}$, Ulaş Aday ${ }^{1}$, Aziz Serkan Senger ${ }^{1}$, Selçuk Gülmez ${ }^{1}$, Sabiye Akbulut ${ }^{2}$, Mustafa Duman ${ }^{1}$

${ }^{1}$ Kartal Koşuyolu Yüksek Ihtisas Eğitim ve Araştırma Merkezi, Gastroenteroloji Cerrahi Kliniği, İstanbul, Türkiye

${ }^{2}$ Kartal Koşuyolu Yüksek Ihtisas Eğitim ve Araştırma Merkezi, Gastroloji Kliniği, İstanbul, Türkiye

\section{ÖZET}

Giriş ve Amaç: Son yıllarda özefagogastroduodenoskopi (ÖGD)'nin yaygın olarak kullanılması ile birlikte üst gastrointestinal sistem poliplerine daha sık rastlanmaktadır. Gastrik poliplerin çoğu asemptomatik olmakla birlikte, malignite potansiyeli taşıdıkları için önemlidir ve tedavi edilmezse gastrik kanser gelişebilir.

Gereç ve Yöntem: Ocak 2013-Haziran 2016 tarihleri arasında herhangi bir nedenle Kartal Koşuyolu Yüksek Ihtisas Eğitim ve Araştırma Hastanesinde ÖGD yapılan 12,563 hasta retrospektif olarak kayıt edildi. Histopatolojik olarak kanıtlanmış en az bir polibi bulunan hastalar çalısmaya dahil edildi.

Bulgular: Kliniğimizde son 3,5 yılda yapılan 12,563 üst gastrointestinal sistem endoskopisi incelenmiş olup 353 (\%2,8)'ünde polipoid lezyon saptanmıştır. Ortalama yaş 56,3 $\pm 12,818-85$ yaş) idi ve hastaların $241(\% 68,3)^{\prime} i$ kadın, $112(\% 31,7)$ 'si erkekti. Endoskopik incelemede poliplerin çoğu antrumda $(\% 50,1)$ ve $1 \mathrm{~cm}$ 'nin altında $(69,5 \%)$ idi. Patoloji değerlendirmesinde en sık hiperplastik polip (HP) (n=151, \%42,8) ve fundik gasttrik polip (FGP) $(n=51, \% 14,4)$ saptandı. 298 hastada polip dışı gastrik mukoza değerlendirilmesinde olguların \%34,9 unda $H$. pylori pozitifliği, $\% 19,4$ 'ünde intestinal metaplazi ve $\% 11,4$ 'ünde ise atrofik gastrik saptandı.

Sonuç: Üst gastrointestinal sistem poliplerine özgü bir semptom olmaması nedeniyle genellikle tesadüfi olarak saptanırlar. Malign dönüşüm potansiyeli var olduğundan saptandıkları zaman polipektomi yapılması gerekmektedir.

Anahtar Kelimeler: Üst gastrointestinal sistem, polip, endoskopi, hiperplastik polip, fundik gastrik polibi

DOi: 10.5578/turkjsurg.4155 